\title{
Performance Analysis of Installed Solar PV System Using Homer in Tanzania: A Case Study of Zanzibar and Arusha
}

\author{
Mohammed Haji", Eugene Park, Thomas Kivevele \\ Department of Materials, Energy Science and Engineering, The Nelson Mandela African Institution of Science and Technology (NM-AIST), \\ Arusha, Tanzania \\ Email address: \\ edimhaji@live.com (M. Haji), eugene.park@nm-aist.ac.tz (E. Park), thomas.kivevele@nm-aist.ac.tz (T. Kivevele) \\ ${ }^{*}$ Corresponding author
}

\section{To cite this article:}

Mohammed Haji, Eugene Park, Thomas Kivevele. Performance Analysis of Installed Solar PV System Using Homer in Tanzania: A Case Study of Zanzibar and Arusha. American Journal of Electrical Power and Energy Systems. Vol. 8, No. 1, 2019, pp. 11-22.

doi: $10.11648 /$ j.epes.20190801.12

Received: November 4, 2018; Accepted: February 7, 2019; Published: March 6, 2019

\begin{abstract}
This study reflects two photovoltaic (PV) power generations, at Karume Institute of Science and Technology (KIST) - Zanzibar and The Nelson Mandela African Institution of Science and Technology (NM-AIST) - Arusha in Tanzania. The output data sets from each site were verified for possible PV simulation of different operational scenarios to obtain the optimum design configuration. The HOMER software was used to analyze the entire operation of the system. The effect of the accuracy of the photovoltaic integration was determined by analysis of different operational behaviors of the simulated PV levels. Furthermore, the overall performance of the station per site was analyzed for technical, economic and environmental constraints as well as their comparative cost-benefit analysis. The study finds that there is a high sensitivity in the demand for the load (i.e. load growth) whose system performance is characterized with minimum: total net present cost (NPC) of $\$ 474,745$ and $\$ 29,169$, feed in tariffs, levelized cost of energy (LCOE) of $\$ 1.06 / \mathrm{kWh}$ and $\$ 0.0118 / \mathrm{kWh}$, total energy output and renewable fraction of $15 \%$ and $22 \%$ for KIST and NM-AIST respectively, thus support the use of photovoltaic power sources in the generation of energy than their counterpart alternatives because of the best technical performance and is less dependent on other external sources of energy, and simultaneously has good economic and environmental performance
\end{abstract}

Keywords: Solar PV System, Performance, Analysis, HOMER, Economic Simulation

\section{Introduction}

Renewable energy is the energy that is not depleted as it is continuously replenished when utilized. This includes solar energy, wind energy, hydro and geothermal energy. Solar PV is derived from the conversion of sunlight to electrical energy using photovoltaic cells. The electrical energy generated can be used in off grid power system or supplied to the main grid when it reaches substantial amounts. This feature makes Solar PV one of the most important renewable energy sources that will potentially contribute significantly to the energy deficit in Tanzania [1].

The utilization of Solar PV as the source of energy will certainly minimize greenhouse gases emissions and adverse climate changes which world is currently experiencing such as droughts and loss of species diversity on planet. Solar PV seem to be a more promising renewable energy source due to frequency of sunlight radiation the country receives throughout the year [2]. The frequency of sunlight and the geographical position of Tanzania across the equator make solar energy to be an ideal renewable source of energy, which will substitute the use of fossils fuels in the country. However, measuring the performance of Solar PV system in order to determine the potential of the solar PV utilization and optimization in Tanzania is the focus of this paper.

Renewable energy therefore will ensure and facilitate the development of clean energy development as well as the national sustainable energy development agendas [3].

Decline in reserve and drastically rise of price of fossil fuels as well as their impacts on the world climate change due to exceedingly greenhouse gases emission [4]. The situation has made Tanzania to strategically planning to employ the use of renewable energy particularly the solar PV and hydroelectric power. 


\section{HOMER Software}

The performance and improvement on any solar systems differs from one geographical location to another and the component features of the solar panel as described by the Hybrid Optimization Modeling for Electric Renewable (HOMER) software. The HOMER software performs: energy balance calculations, system cost calculations for each system configuration, listing of all the possible system sizes, and sorts them by Net Present Cost (NPC). HOMER is made of several energy components, and is used to evaluate suitable options for considering cost against availability of energy resources [5].

The HOMER design procedure is a major consideration when making Grid connections, - where initial information namely energy resources, possible economic and technical constraints, energy storage requirements and control strategies of the systems are accounted for beforehand. Other essential inputs considered include component type, operation, capital, replacement and maintenance costs, efficiency and operational life. Besides being required in the grid connection, the aforementioned inputs are also vital in the stand-alone systems, and are applicable in both installed energy sources and conventional systems [6].

Most of the demonstration and experimentation of the PV systems, as alternative sources of renewable energy focus on installation will minimal, if any, investigation given to study the feasibility and optimal combination of resources. Several constraints in line with feasibility and optimal resource allocation have resulted into failures in meeting the required load demand and related economic sustainability.

A case study of the application of the HOMER software is by Bernal-Agustín and Dufo-Lopez [7], used it for Optimization and Simulation of Solar Photovoltaic cell in a residential building in Malviya Nagar, India. The optimization of the solar photovoltaic cell on the residential building, which had a total roof area of $576 \mathrm{~m}^{2}$ and had 16 flats, was done using HOMER software. The average solar radiation data of the location as well as the cost of the different component required for the setup was observed. The optimization output was $160 \mathrm{~kW}$ PV cell which was required at a cost of $\$ 0.184$ for electricity generation.

Conversely, Anwari, Rashid [8] presented a photovoltaic power system simulation for small industry area in Malacca, Malaysia. The modeling and simulation of $1 \mathrm{MW}$ grid connected PV system was simulated using the National Renewable Energy Laboratory's (NREL) HOMER software, and the optimum system was analyzed for the economic feasibility. The system was expected to foresee reduced grid energy consumption while simultaneously reduce greenhouse gases emissions. The HOMER software simulated the system and performance optimization of system was done using both secondary usage data and the renewable solar radiation data. Results indicated that both the lifecycle and cost of each system modules duly affected the optimization and confirmed the significant efficiency of the proposed approach to the development of renewable energy systems with PV power generators.
In a dissimilar scenario, Ani and Abubakar [9] calculated feasibility analysis and simulation of integrated renewable energy system for power generation in his hypothetical study of integrated renewable energy (IRE) in rural health clinic in Borno State in Nigeria, using solar photovoltaic (PV) and wind turbine (WT) systems. The results indicated that the energy output from the integrated systems was suitable for deployment of $100 \%$ clean energy for uninterruptable power supply with optimum performance in the health clinic. It was concluded that, with a low energy health facility, it is possible to meet the entire annual energy demand of a health clinic solely through a stand-alone integrated renewable $\mathrm{PV} /$ wind energy supply without grid-connection.

Besides, the performance of the integrated system on the grid-tied connection needs to be assessed. This includes evaluating the implication of the grid-connected PV system to the total power output of the systems as well as the PV generation on the entire system. The key factors to consider are the: sensitivity and the suitability in enhancing the overall output, feasibility factors, cost-effectiveness, data provision on PV system under grid connection, the system optimization parameters to the consumer etc [10].

This study, therefore, evaluates and analyzes the performance of grid-connected solar PV of $75.63 \mathrm{~kW}_{\mathrm{p}}$ and $0.3 \mathrm{kWp}$ at Karume Institute of Science and Technology and Nelson Mandela African Institution of Science and Technology respectively.

\section{Methodology}

The instrument used in this study were multimeter (model INNOVA 3300), for measuring short circuits currents and open circuit voltages of the PV modules. The short-circuit current $\left(\mathrm{I}_{\mathrm{sc}}\right)$ is the current through the solar PV when the voltage across the solar cell is zero (i.e., when the solar PV is short-circuited) and the open-circuit voltage, $\mathrm{V}_{\mathrm{oc}}$, is the maximum voltage available from a solar cell, and this occurs at zero current.

Because any successful evaluation requires proper application of prerequisite standards on site data to facilitate correct analysis of the operational behavior of all possible scenarios, the following analysis framework for site specification, verification of demonstrated data sets (i.e., solar energy, solar insolation and load demand), system analysis and operational performance impact were employed.

\subsection{Site Specifications}

KIST is located at the latitude $-6.16\left(6^{\circ} 09^{\prime} 36^{\prime \prime} \mathrm{S}\right)$, longitude $+39.2\left(39^{\circ} 12^{\prime} 00^{\prime \prime} \mathrm{E}\right)$ and altitude $0 \mathrm{~m}$ at a distance of $72 \mathrm{~km}$ above the Indian Ocean while NM-AIST is located at the latitude -3.4 ( $3^{\circ} 24^{\prime} 0$ '’S), longitude +36.78 (36 $46^{\circ} 8$ 'E) Arusha region on north of Tanzania.

\subsection{Technical Data}

Solar panels are rated to perform according to their specifications under standard test conditions (STC) - a 
condition that can be created in a lab to allow easy measurement and comparison. The defined STC for solar is a panel pointed directly at a bright sun with $1000 \mathrm{~W}$ of solar energy landing per square meter, with the panel kept at $25^{\circ} \mathrm{C}$ $\left(77^{0} \mathrm{~F}\right.$ ) and an atmospheric mass (a number that refers to the amount of atmosphere between the panel and the sun) of 1.5 overhead. Table 1 illustrates technical details for the existing system and the module specifications are shown in Table 2.

Table 1. Technical detail of the systems.

\begin{tabular}{llll}
\hline Designation & KIST Administration & KIST dining hall & NM-AIST \\
\hline Power & $25.21 \mathrm{~kW}_{\mathrm{p}}$ & $50.42 \mathrm{~kW}_{\mathrm{p}}$ & $0.3 \mathrm{kWp}$ \\
Area & $176.94 \mathrm{~m}^{2}$ & $353.88 \mathrm{~m}^{2}$ & $4.07 \mathrm{~m}^{2}$ \\
Tracking system & Without tracking system & & \\
Tilt & $30^{\circ}$ & & $>10 \mathrm{~cm}$ \\
Orientation & $0^{\circ}$ & 15 & 2017 \\
Type of installation & Roof top installation, small distance $(<10 \mathrm{~cm})$ & 2 \\
System start-up & $31 / 10 / 2013$ & 2 & 2 \\
Series-connected & 15 & & \\
Parallel-connected & 2 & 6 & WINKLE POWER \\
Inverter type & SMA SMC 8000TL & 180 & Si-3000S \\
Number of inverters & 3 & 4 \\
Module type & Hanwha SF260 Poly $(280 \mathrm{~W})$ & \\
Number of modules & 90 & & \\
\hline
\end{tabular}

Table 2. PV module specifications.

\begin{tabular}{|c|c|c|c|c|c|c|}
\hline \multirow{2}{*}{ Quantity } & \multirow{2}{*}{ Symbol } & \multirow{2}{*}{ Unit } & \multicolumn{2}{|c|}{ KIST Values } & \multicolumn{2}{|c|}{ NM-AIST Values } \\
\hline & & & STC & NOCT & STC & NOCT \\
\hline Maximum power rating & $P_{\max }$ & W & 280 & 204 & 150 & 108 \\
\hline Open circuit voltage & $\mathrm{V}_{\mathrm{oc}}$ & V & 44.3 & 40.8 & 22.19 & 20.2 \\
\hline Sort-circuit current & $\mathrm{I}_{\mathrm{sc}}$ & A & 8.45 & 6.84 & 8.62 & 6.9 \\
\hline Rated voltage at max. power & $\mathrm{V}_{\mathrm{mpp}}$ & V & 36.2 & 32.9 & 18.16 & 16.2 \\
\hline Rated current at max. power & $\mathrm{I}_{\mathrm{mpp}}$ & A & 7.87 & 6.21 & 8.06 & 6.7 \\
\hline Weight & $\mathrm{W}$ & $\mathrm{Kg}$ & 11.6 & & 12 & \\
\hline Dimensions & - & $\mathrm{mm}$ & $1483 *$ & & $1510 *$ & \\
\hline Maximum system voltage & $\mathrm{V}_{\max }$ & $\mathrm{V}_{\mathrm{DC}}$ & 1000 & & & \\
\hline Wind resistance & - & $\mathrm{P}_{\mathrm{a}}$ & 2400 & & & \\
\hline
\end{tabular}

\subsection{Current and Voltage Measurements of the Solar PV Systems}

The open-circuit voltage $\left(\mathrm{V}_{\mathrm{oc}}\right)$ and the short-circuit current $\left(\mathrm{I}_{\mathrm{sc}}\right)$ cannot be measured at the same time because they correspond to different operating modes of the device. At open-circuit, which is the case a voltmeter with a high input impedance (several Mega-ohms) was connected to solar PV, the excess carriers cannot leave the device with the result that the external current is zero. Subsequently, all carriers are forced to recombine and the recombination rate equals the generation rate under steady state conditions [11].

In a grid connected, the current was measured by using a coil wound round the PV inductor and connect the coil to the second data logger channel to measure the output voltage on the coil. These measurements were taken under the tag energy meter per day from 7:15 to $17: 30$ hours and their average values in each month. Table 3 shows grid connected system parameters at KIST.
Table 3. Grid connected measurement parameters at KIST.

\begin{tabular}{lllll}
\hline \multirow{2}{*}{ Month } & \multicolumn{3}{l}{ D. C Values } & \multicolumn{2}{l}{ C Values } \\
\cline { 2 - 5 } & I [A] & V [V] & I [A] & V [V] \\
\hline JAN & 11.64 & 442.30 & 17.21 & 243.67 \\
FEB & 11.45 & 418.56 & 17.23 & 242.45 \\
MAR & 10.34 & 411.43 & 16.98 & 243.98 \\
APR & 9.02 & 421.34 & 14.39 & 244.12 \\
MAY & 8.84 & 402.70 & 14.76 & 222.43 \\
JUN & 9.75 & 442.10 & 15.61 & 244.51 \\
JUL & 11.02 & 443.26 & 17.58 & 241.98 \\
AUG & 11.75 & 412.30 & 17.76 & 241.73 \\
SEP & 12.12 & 431.50 & 17.97 & 228.74 \\
OCT & 12.50 & 421.45 & 17.23 & 231.56 \\
NOV & 12.67 & 414.48 & 18.12 & 229.85 \\
DEC & 12.83 & 426.97 & 18.43 & 228.78 \\
\hline
\end{tabular}

The d.c voltage current and power measurements for NMAIST system is represented in Table 4 as recorded from the data logger 
Table 4. Measurements taken from solar PV in NM-AIST.

\begin{tabular}{llllll}
\hline CURRENT (A) & BATTERY VOLTAGE (V) & NORTH VOLTAGES (V) & SOUTH VOLTAGES (V) & TOTAL VOLTAGES (V) & POWER (W) \\
\hline 24.81 & 28.95 & 25.78 & 25.97 & 28.53 & 707.84 \\
6.87 & 28.9 & 25.57 & 25.92 & 28.53 & 196.08 \\
18.58 & 28.9 & 25.57 & 25.8 & 25.24 & 468.82 \\
39.35 & 28.95 & 25.53 & 25.75 & 28.14 & 1107.13 \\
24.9 & 28.95 & 25.57 & 25.75 & 27.08 & 674.15 \\
24.71 & 28.95 & 25.66 & 25.8 & 24.4 & 602.92 \\
4.56 & 28.95 & 25.57 & 25.75 & 28.53 & 130.04 \\
7.39 & 28.95 & 25.57 & 25.75 & 28.53 & 127.6 \\
4.74 & 28.95 & 25.57 & 25.88 & 26.91 & 185.45 \\
6.5 & 28.95 & 25.57 & 25.88 & 14.58 \\
0.55 & 28.9 & 25.57 & 25.71 & 28.53 & 23.42 \\
0.89 & 28.9 & 25.84 & 26.52 & 27.89 \\
1.05 & 28.9 & 25.66 & 25.8 & 26.44 & 110.1 \\
3.58 & 28.9 & 25.57 & 25.75 & 26.46 & 71.32 \\
4.17 & 28.9 & 25.57 & 26.27 & 51.81 \\
2.7 & 28.9 & 25.57 & 25.75 & 26.38 & 42.06 \\
1.96 & 28.9 & 25.57 & 25.8 & 26.44 & 70.8 \\
1.59 & 28.9 & 25.57 & 25.88 & 26.44 & 51.81 \\
2.69 & 28.95 & 25.66 & 25.8 & 26.44 & 43.52 \\
1.96 & 28.95 & 25.61 & 25.88 & 65.28 \\
1.65 & 28.9 & 25.57 & 25.75 & 26.49 & 48.86 \\
2.47 & 28.9 & 25.57 & 25.88 & 26.38 & \\
1.85 & 28.9 & 25.57 & & 26.38 & \\
\hline
\end{tabular}

\subsection{The Existing PV System}

An electrical grid is an interconnected network for delivering electricity from suppliers to consumers and investigated in the present study is shown in the Figure 1.

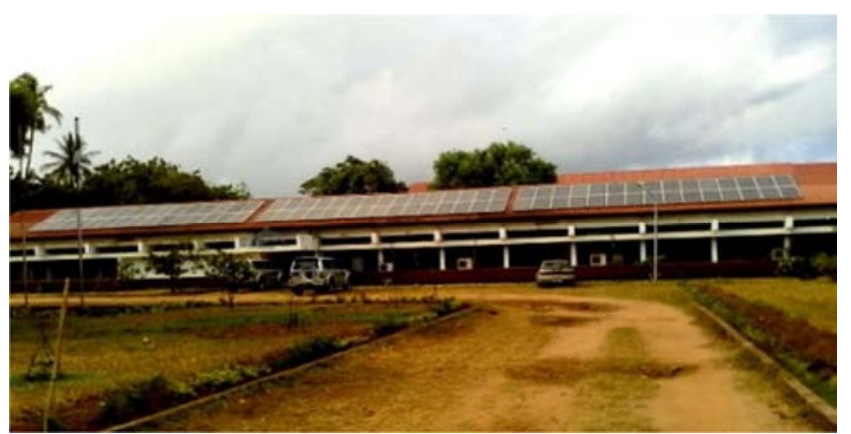

(a)

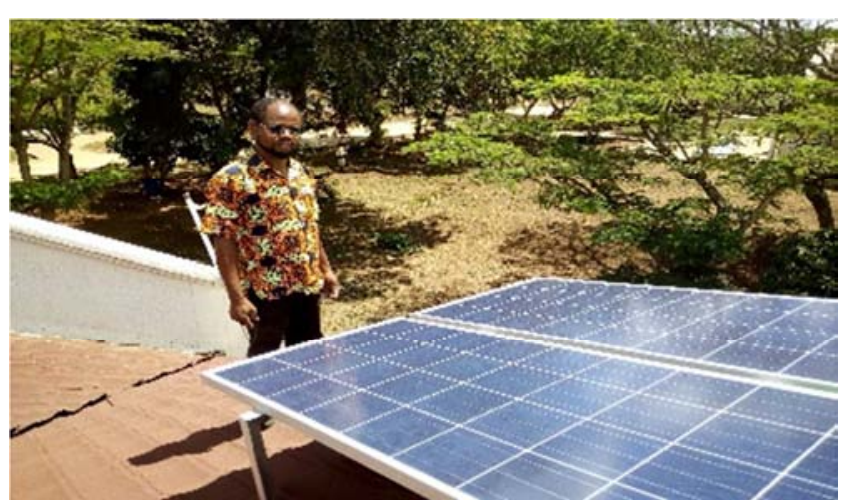

(b)

Figure 1. PV system (a) PV system at KIST (b) PV system at NM-AIST.

The existing block diagram for the systems are as shown in Figure 2 and Figure 3 for KIST and NM-AIST respectively.

Solar Array
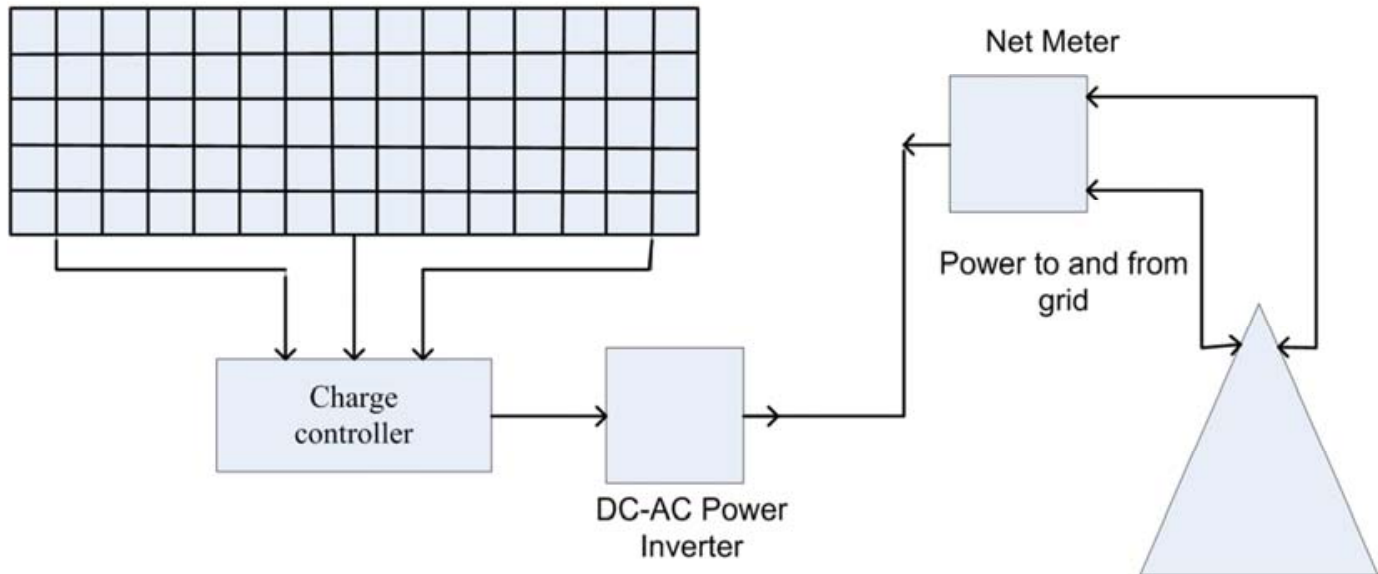

Figure 2. Block diagram of KIST PV system. 


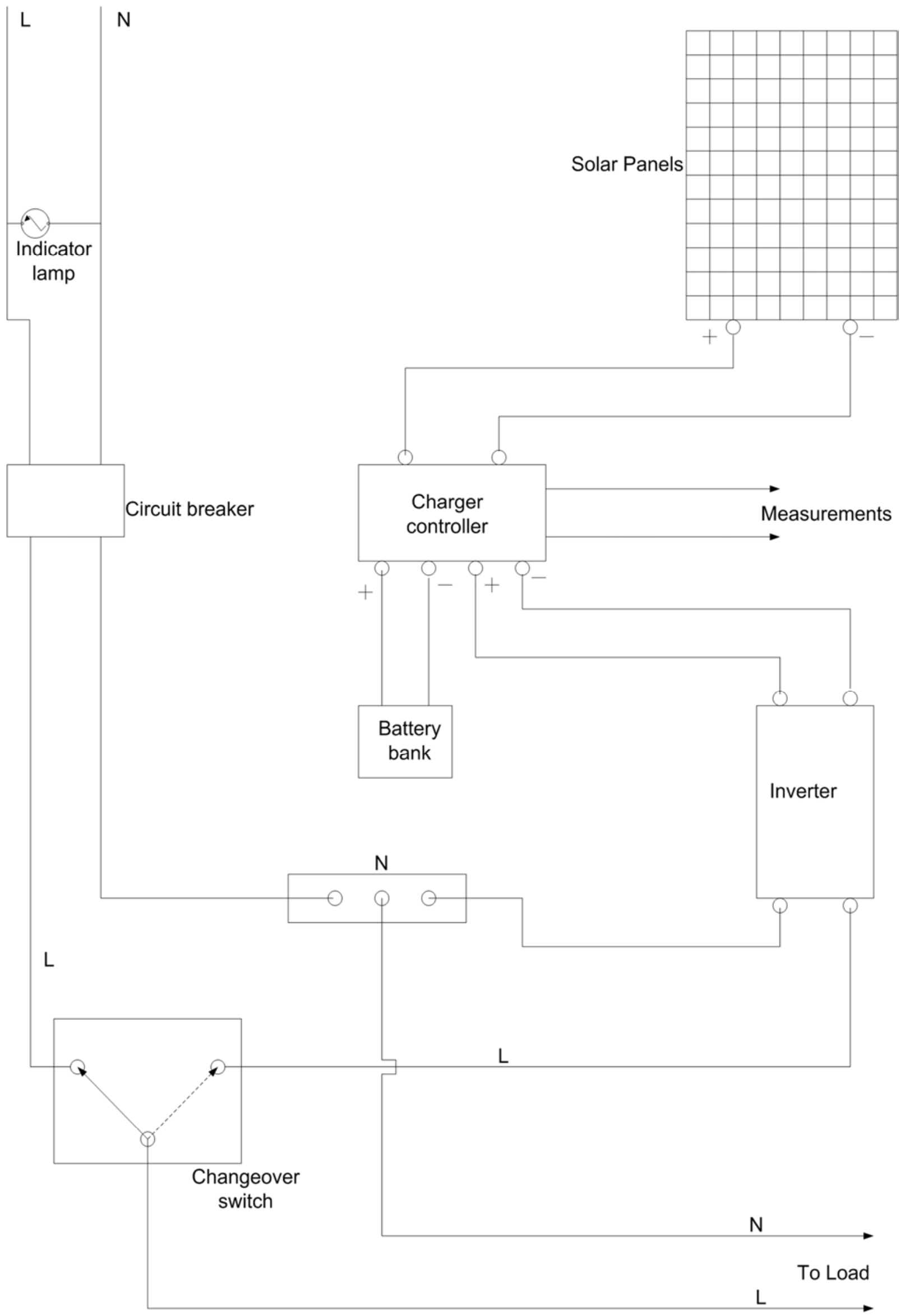

Figure 3. NM-AIST PV System arrangement. 


\subsection{Data Verifications and System Configuration}

The system data parameters taken were solar radiation, ambient temperature, load profile and demand data as shown in Figure 4 and 5. The real-time measurement of solar irradiation and ambient temperature data was done in order to assess the optimum performance of the system. However, due to the internal limitations within the system namely faulty sensors and measuring tools, the measured data was limited. Nonetheless, the missing data was compensated by that obtained from National Aeronautics and Space Administration (NASA), - which was used as another input data.

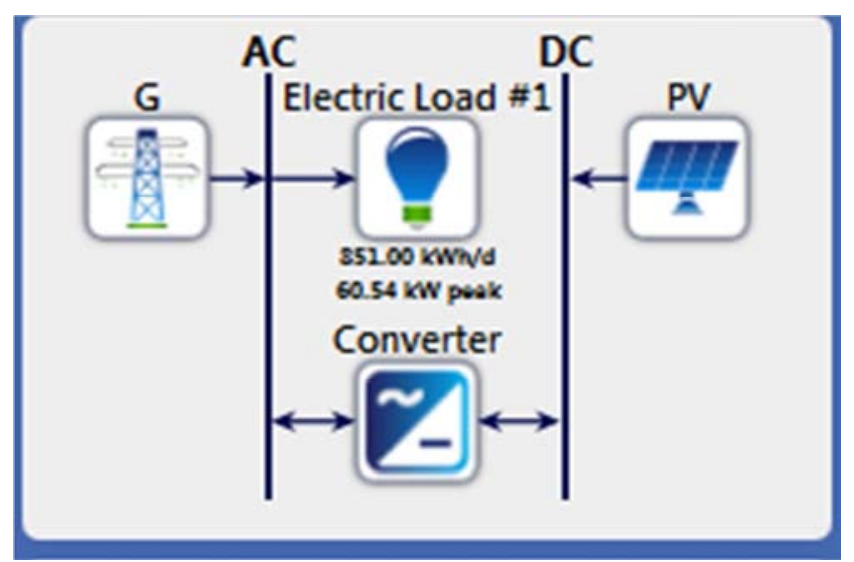

(a)

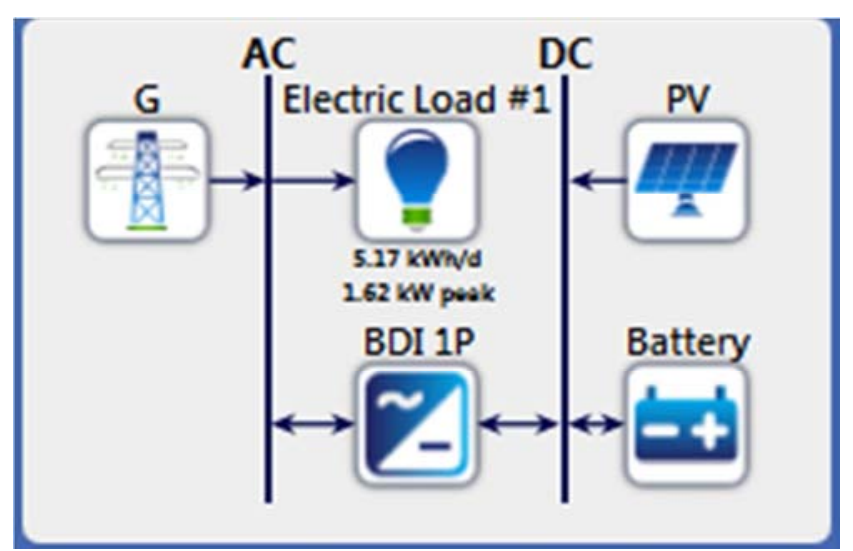

(b)

Figure 4. Configuration (a) KIST and (b) NM-AIST.

\subsection{Solar Resource}

Solar insolation data obtained from NASA's website, in the event of unavailability of sufficient measured data in the desired locations [12]. Monthly solar insolation data for both locations are generally in the range of $4.3-6.52$ $\mathrm{kWh} / \mathrm{m}^{2} /$ day, with an annual average of 5.39 and 5.58 $\mathrm{kWh} / \mathrm{m}^{2} /$ day for NM-AIST and KIST respectively as presented in Table 5.

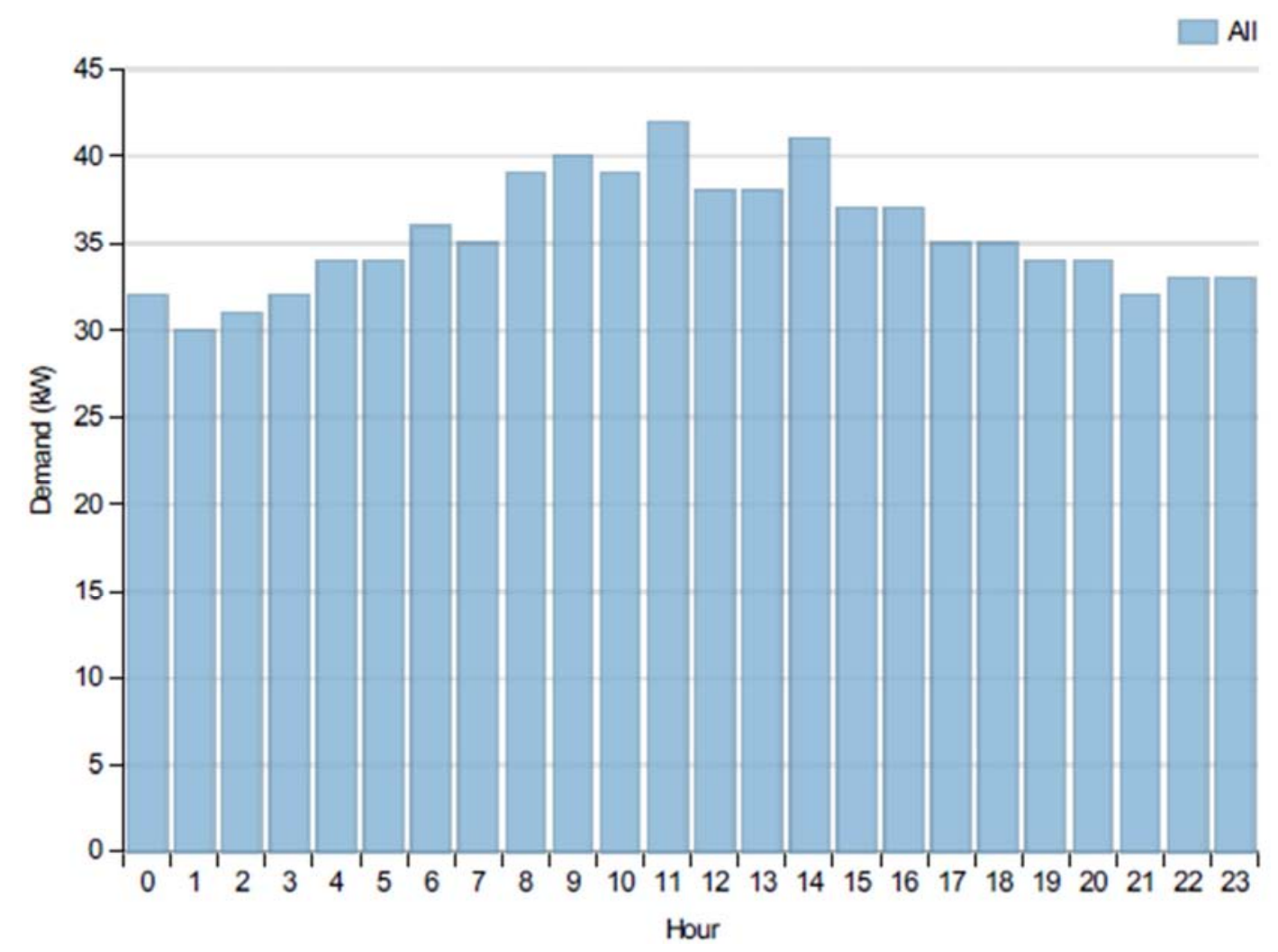

(a) 


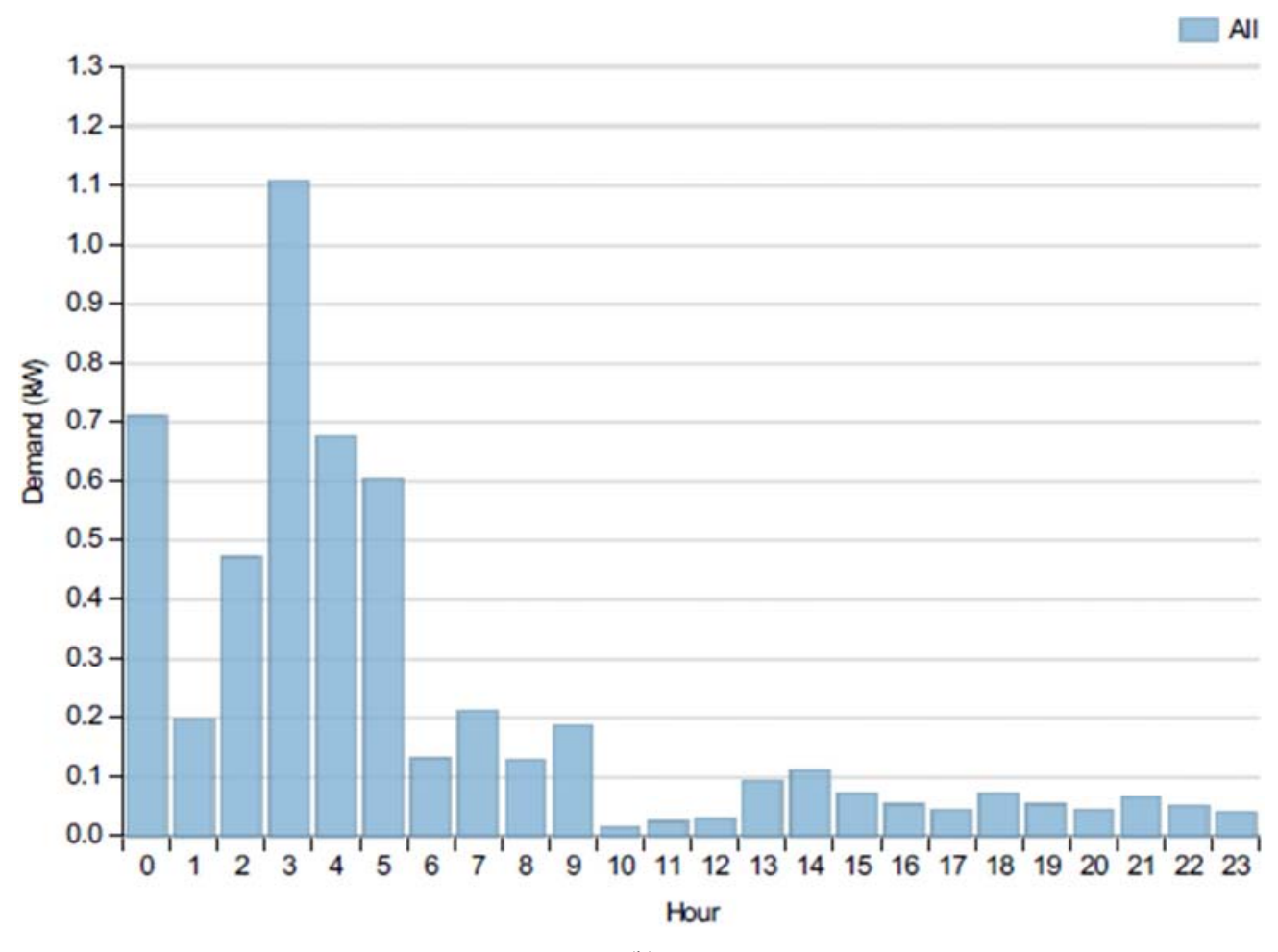

(b)

Figure 5. Load curves (a) KIST and (b) NM-AIST.

Table 5. Systems solar resources.

\begin{tabular}{lll}
\hline Quantity & KIST & NM-AIST \\
\hline Sizes to consider $(\mathrm{kW})$ & $30,40,50,70,80$ & $0.3,0.4,0.5,0.6,1$ \\
Lifetime & 25 years & \\
Derating factor & $80 \%$ & \\
Tracking system & No tracking & 3.400 degrees \\
Slope & 6.216 degrees & \\
Azimuth & 180.000 degrees & \\
Ground reflectance & $20.0 \%$ & \\
\hline
\end{tabular}

\subsection{Load Demand}

Demand profiles were made using year 2016 and 2017 load data sets collected during the KIST site visits. Variations in temperature were taken for the remaining months and the corresponding average load was scaled accordingly [13]. The load growth was based on sensitivity analysis in the HOMER software as shown in Table 6.

Table 6. System input load.

\begin{tabular}{lll}
\hline LOAD & KIST & NM-AIST \\
\hline Data source & Synthetic & Synthetic \\
Daily noise & $10 \%$ & $10 \%$ \\
Hourly noise & $10 \%$ & $10 \%$ \\
Scaled annual average & $851.000 \mathrm{kWh} / \mathrm{d}$ & $5.167 \mathrm{kWh} / \mathrm{d}$ \\
Scaled peak load & $60.5395 \mathrm{~kW}$ & $1.6159 \mathrm{~kW}$ \\
Load factor & 0.5857 & 0.1332 \\
\hline
\end{tabular}

Once average load datasets were entered into the prototypical, variability must be introduced using HOMER's time step sensitivity capacity factor and day-to-day PV penetration functions. Appropriate values of these were determined to be $18.79 \%$ and $26.18 \%$, respectively, in NM-
AIST and KIST $19.45 \%$ and $16.45 \%$ respectively.

\subsection{System Components}

Both stations were installed and each consists of several components (PV arrays, bidirectional converters and batteries for NM-AIST only). KIST was commissioned in October 2013 and expected to produce $75.63 \mathrm{kWp}$. On the other hand, NM-AIST was commissioned in July 2017 and expected to produce $0.3 \mathrm{kWp}$.

\subsubsection{PV Module}

PV system is employed to supply electrical power during the day from 7:15 am to $5: 30 \mathrm{pm} \pm 15 \mathrm{~min}$, when there is sunshine, otherwise, battery banks take the role to supply the load in NM-AIST but in KIST there is no battery bank. In this study, all inputs are shown in Table 7.

Table 7. System inputs to $P V$.

\begin{tabular}{lllll}
\hline Site & Size $(\mathbf{k W})$ & Capital & Replacement & O\&M \\
\hline KIST & 0.28 & $\$ 1,100.00$ & $\$ 660.00$ & $\$ 10.00$ \\
NM-AIST & 0.15 & $\$ 600.00$ & $\$ 400.00$ & $\$ 10.00$ \\
\hline
\end{tabular}

\subsubsection{Bidirectional Converter}

Converters' size is compatible with the PV arrays for KIST and NM-AIST, the size to ensure full supply of PV power and was taken as $100 \mathrm{~kW}$ and $1 \mathrm{~kW}$ respectively. The capital and replacement costs of the converters are 3,000 $\$ / \mathrm{kW}, 600$ $\$ / \mathrm{kW}$ and $1,800 \$ / \mathrm{kW}, 600 \$ / \mathrm{kW}$ respectively, while 10 $\$$ year and 0 \$/year are marked for operating and maintenance costs respectively. The operational lifetime was considered to be 10 years. The sizes are considered to 25.21, 


\section{0, 50.42, 75.63, $100 \mathrm{~kW}$ for KIST and $5 \mathrm{~kW}$ for NM-AIST.}

\subsubsection{Battery Energy Storage}

Lead acid type $1 \mathrm{kWh}$ of energy storage batteries is employed in NM-AIST sites, each cell is made up of $12 \mathrm{~V}$, and connected as four strings, each string with a maximum capacity of $4.0 \mathrm{~kW}, 83.4 \mathrm{Ah}$ and contains 4 units. The capital, replacement and operating and maintenance costs are 300 $\$ / \mathrm{kW}, 300 \$ / \mathrm{kW}$ and $10 \$ / \mathrm{kW}$ respectively. KIST system has no battery storage.

\subsection{Operating Strategies}

Under normal operating conditions, the insolation is abundantly available and SPV control system gives the highest priority PV arrays to supply the loads. In the case of excess energy supply, the system automatically charges the battery to full capacity beyond which the excess energy is used by dumped loads. However, in case of insufficient energy from the PV system, the battery supply loads until the minimum state of charge is reached. The charging/discharging the battery happens every hour, and is based on the energy balance computations made within the system due to ultimate decision of the control system of the energy sources.
Hence, the reliable based on the amount of power supplied when PV quantity abruptly decreases and/ or the load demand suddenly increases. In this study, the operating reserve values were $15 \%$ and $22 \%$ for KIST and NM-AIST respectively of the renewable fraction that represents the fraction of the energy delivered to the load that produced from renewable power sources.

\section{Results}

The simulation results for the technical, economic and environmental analyses including sensitivity of the PV system configurations show that the effects of solar PV in cost, net production costs, feed-in-tariff, inverter prices, battery prices and demand growth over the years is high. The simulations from the HOMER software as well as the results for each station analysis are presented below (Sections 3.1 to 3.7) for both existing systems of implemented by HOMER.

\subsection{Hourly Time Series Analysis}

The hourly time series shown in Figures 6 and 7 for KIST and NM-AIST respectively.

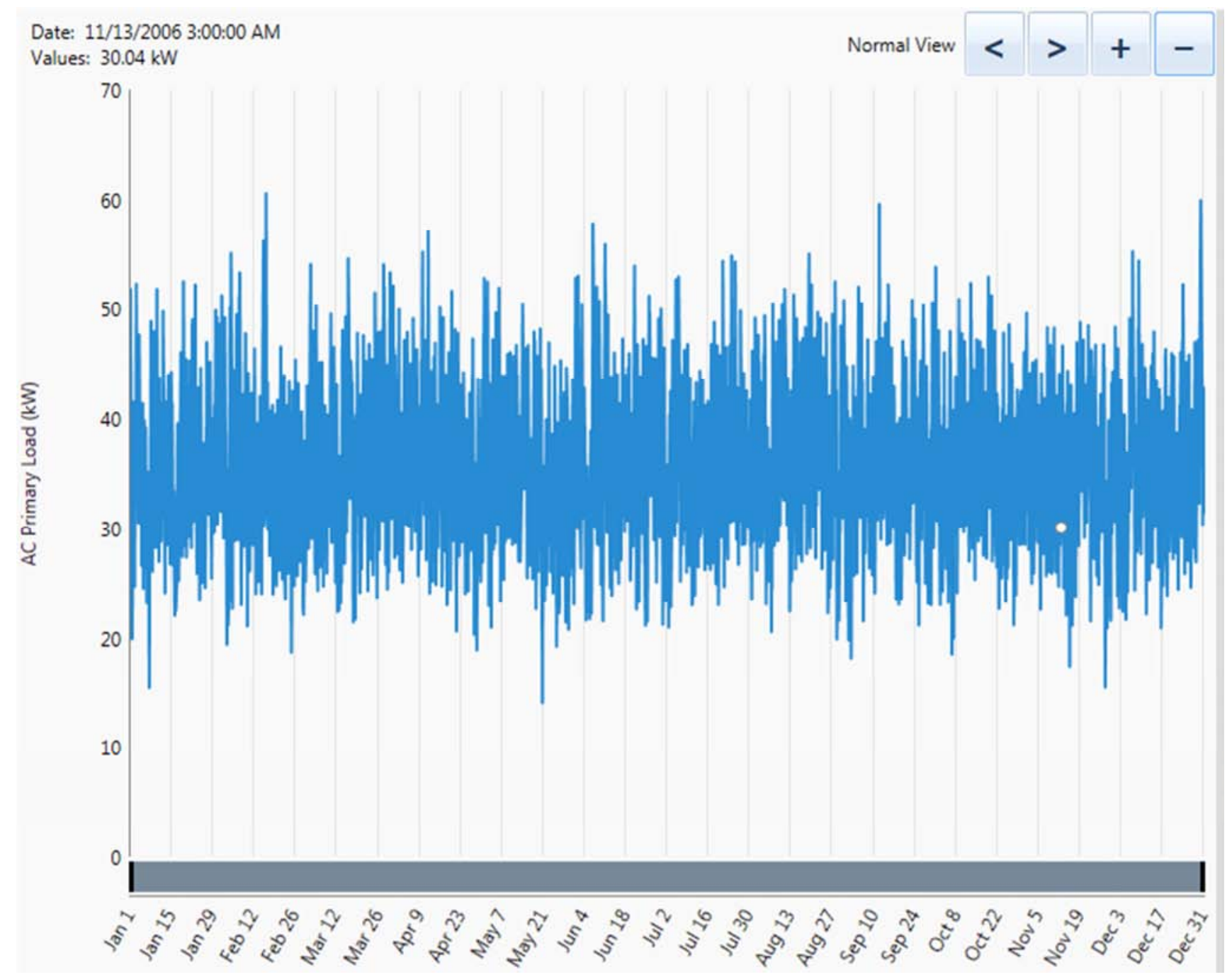

Figure 6. KIST hourly time series analysis results. 


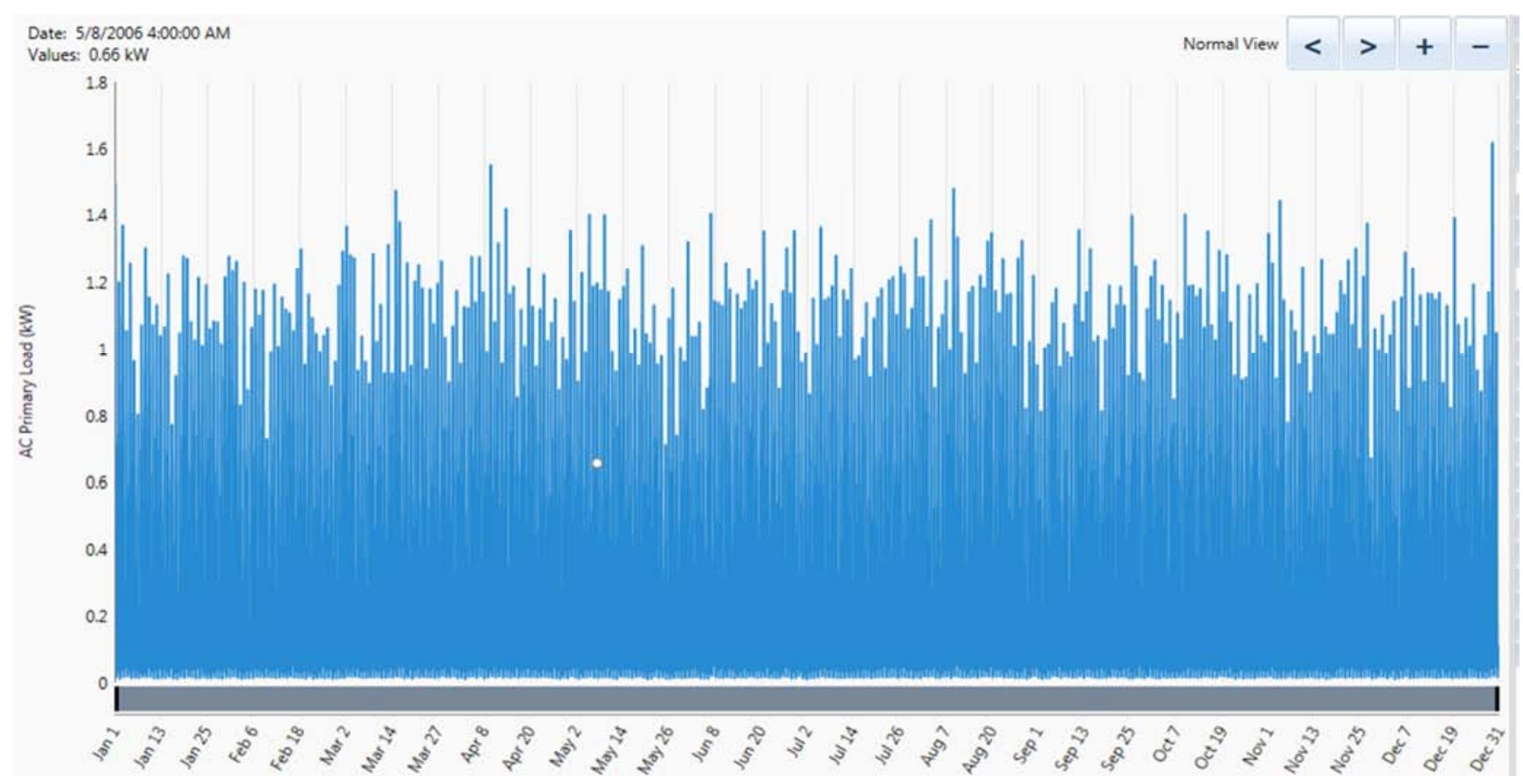

Figure 7. NM-AIST hourly time series analysis results.

\subsection{Sensitivity and Optimization Cases Results}

A sensitivity analysis by entering multiple values for a particular input variable, hence an input variable for which you have specified multiple values is called a sensitivity variable. The systems sensitivity are $0.3 \mathrm{~kW}$ PV with net present cost $\$ 29,169$ and $30 \mathrm{~kW}$ PV with net present cost $\$ 474,475$ for KIST and NM-AIST respectively. Other results are as shown in Figures 8 and 9.

\subsection{Renewable Penetration}

The penetration of renewable energy was compared to the amount of electricity consumed. In this context, renewable penetration refers to the percentage of electricity generated by a particular resource as the percentage relative to the total amount of electricity generated, or the amount consumed.

\subsection{Grid}

In grid systems, the capital cost, the replacement cost and the fuel cost of the grid are always zero. The operating and maintenance cost is equal to the annual cost of buying electricity from the grid (energy cost plus demand cost) minus any income from the sale of electricity to the grid as shown in Figure 10 for KIST and NM-AIST respectively.

\begin{tabular}{|c|c|c|c|c|c|c|c|c|c|c|c|c|c|c|c|}
\hline & \multicolumn{3}{|c|}{ Export... } & \multicolumn{3}{|c|}{ Column Choices... } & & & & \multicolumn{6}{|c|}{ Sensitivity Cases: Left Click on sensitivity case to see optimization cases. } \\
\hline \multicolumn{10}{|c|}{ Architecture } & \multicolumn{4}{|c|}{ Cost } & \multirow{2}{*}{$\begin{array}{c}\text { System } \\
\text { Ren Frac } \nabla \\
(\%)\end{array}$} & \\
\hline \multirow[t]{2}{*}{$\triangle$} & T & $\Rightarrow$ & A: & z & $\begin{array}{l}\mathrm{PV} \\
(\mathrm{kW})\end{array}$ & Battery $\checkmark$ & ${ }_{(\mathrm{kW})}^{\mathrm{G}} \mathrm{P}$ & $\begin{array}{c}\text { BDI 1P } \\
(\mathrm{kW})\end{array}$ & Dispatch $\checkmark$ & $\begin{array}{c}\mathrm{COE} \\
(\$)\end{array}$ & $\begin{array}{c}N P C \\
(5)\end{array}$ & $\begin{array}{l}\text { Operating cost } \nabla \\
(\$)\end{array}$ & $\begin{array}{c}\text { Initial capital } \checkmark \\
(\$)\end{array}$ & & \\
\hline & $m$ & & $\AA$ & Z & 0.3 & & 999,999 & 5 & $\mathrm{CC}$ & $\$ 1.062$ & $\$ 29,169$ & $\$ 1,931$ & $\$ 4,200$ & 22 & \\
\hline & \multicolumn{9}{|c|}{ Export... } & \multicolumn{6}{|c|}{ Optimization Cases: Left Double Click on simulation to examine details. } \\
\hline \multicolumn{10}{|c|}{ Architecture } & \multicolumn{4}{|c|}{ Cost } & System & \\
\hline \multirow[t]{11}{*}{$\Delta$} & m & $\Rightarrow$ & As: & Z & ${ }_{(\mathrm{kW})}^{\mathrm{PV}} \mathrm{P}$ & Battery $\checkmark$ & ${ }_{(\mathrm{kW})}^{\mathrm{G}} \nabla$ & $\begin{array}{c}\mathrm{BDI} 1 \mathrm{P} \\
(\mathrm{kW})\end{array}$ & Dispatch $\checkmark$ & $\begin{array}{l}\mathrm{COE} \nabla \\
\text { (5) }\end{array}$ & $\begin{array}{c}N P C \\
(5)\end{array}$ & $\begin{array}{l}\text { Operating cost } \nabla \\
\text { (\$) }\end{array}$ & $\begin{array}{c}\text { Initial capital } \checkmark \\
\text { (\$) }\end{array}$ & $\begin{array}{c}\text { Ren Frac } \checkmark \\
(\%)\end{array}$ & \\
\hline & $m$ & & A & $\boldsymbol{Z}$ & 0.3 & & 999,999 & 5 & $\mathrm{cc}$ & $\$ 1.062$ & $\$ 29,169$ & $\$ 1,931$ & $\$ 4,200$ & 22 & \\
\hline & $m$ & & $\AA$ & Z & 0.4 & & 999,999 & 5 & $\mathrm{CC}$ & $\$ 1.000$ & $\$ 29,181$ & $\$ 1,901$ & $\$ 4,600$ & 28 & \\
\hline & $m$ & & $\AA$ & z & 0.5 & & 999,999 & 5 & $\mathrm{CC}$ & $\mathbf{S 0 . 9 4 6}$ & $\$ 29,328$ & $\$ 1,882$ & $\$ 5,000$ & 33 & \\
\hline & $m$ & tet & A & Z & 0.3 & 2 & 999,999 & 5 & $\mathrm{CC}$ & $\$ 1.074$ & $\$ 29,499$ & $\$ 1,945$ & $\$ 4,350$ & 22 & \\
\hline & $m$ & 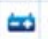 & $\AA$ & z & 0.4 & 2 & 999,999 & 5 & $\mathrm{CC}$ & $\$ 1.012$ & $\$ 29,511$ & $\$ 1,915$ & $\$ 4,750$ & 28 & \\
\hline & 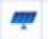 & & \& & Z & 0.6 & & 999,999 & 5 & $\mathrm{CC}$ & $\$ 0.897$ & $\$ 29,531$ & $\$ 1,867$ & $\$ 5,400$ & 37 & \\
\hline & $m$ & ot & $\AA$ & Z & 0.5 & 2 & 999,999 & 5 & $\mathrm{CC}$ & $\$ 0.956$ & $\$ 29,657$ & $\$ 1,896$ & $\$ 5,150$ & 33 & \\
\hline & $m$ & ه & A & z & 0.6 & 2 & 999,999 & 5 & $\mathrm{CC}$ & $\$ 0.907$ & $\$ 29,861$ & $\$ 1,881$ & $\$ 5,550$ & 37 & \\
\hline & $m$ & & A & Z & 1.0 & & 999,999 & 5 & $\mathrm{CC}$ & $\$ 0.750$ & $\$ 30,509$ & $\$ 1,819$ & $\$ 7,000$ & 50 & \\
\hline & m & $\Leftrightarrow$ & A & Z & 1.0 & 2 & 999,999 & 5 & $\mathrm{CC}$ & $\$ 0.759$ & $\$ 30,839$ & $\$ 1,832$ & $\$ 7,150$ & 50 & \\
\hline
\end{tabular}

Figure 8. NM-AIST sensitivity and optimization analysis results. 


\begin{tabular}{|c|c|c|c|c|c|c|c|c|c|c|c|c|c|}
\hline \multicolumn{14}{|c|}{ Seasitivity cases: Overall } \\
\hline \multicolumn{4}{|c|}{ Architecture } & \multicolumn{4}{|c|}{ Cost } & \multirow{2}{*}{\begin{tabular}{|c|} 
System \\
Rea Frac \\
$(\%)$
\end{tabular}} & \multicolumn{2}{|c|}{ PV } & \multicolumn{2}{|c|}{ Converter } & \multirow{2}{*}{\begin{tabular}{|c|} 
G \\
Energy \\
Produced
\end{tabular}} \\
\hline $\begin{array}{l}\mathrm{PV} \\
(\mathrm{kW})\end{array}$ & G & $\begin{array}{c}\text { Coaverter } \\
(\mathbf{k W}\end{array}$ & Dispatch & $\begin{array}{l}\mathrm{COE} \\
\text { (S) }\end{array}$ & NPC (\$) & $\begin{array}{l}\text { Operating } \\
\text { Cost (S) }\end{array}$ & $\begin{array}{c}\text { Initial } \\
\text { Capital (\$) }\end{array}$ & & $\begin{array}{l}\text { Capital } \\
\text { Cost (\$) }\end{array}$ & Production & $\begin{array}{l}\text { Rectifier } \\
\text { Mean } \\
\text { Output }\end{array}$ & $\begin{array}{c}\text { Inverter } \\
\text { Mean } \\
\text { Output }\end{array}$ & \\
\hline 30 & 999.999 & 25.2 & $\mathrm{CC}$ & $\$ 0.118$ & $\$ 474,745$ & $\$ 27,548$ & $\$ 118,613$ & 15 & $\$ 117,857$ & 31,108 & 0 & 3 & 264,624 \\
\hline \multicolumn{14}{|c|}{ Optimiration case: Overall } \\
\hline \multicolumn{4}{|c|}{ Architecture } & \multicolumn{4}{|c|}{ Cost } & \begin{tabular}{|l|} 
System \\
\end{tabular} & \multicolumn{2}{|c|}{ PV } & \multicolumn{2}{|c|}{ Converter } & G \\
\hline $\begin{array}{c}\mathrm{PV} \\
(\mathrm{kW})\end{array}$ & G & $\begin{array}{c}\text { Coaverter } \\
\text { (kW }\end{array}$ & Dispatch & $\begin{array}{l}\mathrm{COE} \\
\text { (\$) }\end{array}$ & NPC (\$) & $\begin{array}{l}\text { Operating } \\
\text { Cost (\$) }\end{array}$ & $\begin{array}{c}\text { Initial } \\
\text { Capital (\$) }\end{array}$ & $\begin{array}{c}\text { Rea Frac } \\
(\%)\end{array}$ & $\begin{array}{l}\text { Capital } \\
\text { Cost (\$) }\end{array}$ & Production & \begin{tabular}{|c|} 
Rectifier \\
Meas \\
Outpat
\end{tabular} & $\begin{array}{l}\text { Iaverter } \\
\text { Meas } \\
\text { Outpat }\end{array}$ & \begin{tabular}{|c} 
Eaerzy \\
Produced
\end{tabular} \\
\hline 30 & 99,999 & 253 & $\mathrm{CC}$ & 0118 & 24745 & $\$ 27,548$ & 613 & $1:$ & $\$ 117,857$ & 51,108 & 0 & 5 & 264,624 \\
\hline 30 & 999.999 & 40.0 & $\mathrm{CC}$ & 50.118 & $\$ 475,294$ & & $\$ 119,057$ & 1 & $\$ 117,857$ & & c & 5 & 254,520 \\
\hline 30 & 999,999 & 50.4 & $\mathrm{CC}$ & 50.118 & 5475,665 & & $\$ 119,370$ & 15 & 17,857 & 51. & c & 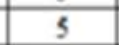 & \\
\hline 30 & 999.999 & 75.6 & $\mathrm{CC}$ & 50.119 & $\$ 476,630$ & & 26 & & 57 & & 0 & 5 & 254,520 \\
\hline 30 & 999.999 & 100.0 & $\mathrm{CC}$ & 50.119 & $\$ 477,544$ & & & 15 & & & 0 & 8 & 520 \\
\hline 40 & 999,999 & & & \$0.124 & 5499,401 & & & - & 143 & & 0 & 7 & 249,348 \\
\hline 40 & 999,999 & 4 & c & 50.124 & $\$ 499,792$ & & 333 & 20 & 7,143 & 14 & s. & 7 & 249,348 \\
\hline 40 & 999,999 & 75.6 & $\mathrm{CC}$ & 50.125 & $\$ 500,737$ & 526,401 & $\$ 159,412$ & 20 & $\$ 157,143$ & 68,114 & 0 & 7 & 249,348 \\
\hline 40 & 999,999 & 25.2 & $\mathbf{c}$ & $\$ 0.125$ & $\$ 501,625$ & $\$ 26,589$ & $\$ 157,899$ & 19 & $\$ 157,143$ & 68,114 & 0 & 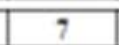 & 252,450 \\
\hline 40 & 999,999 & 100.0 & C & 50.125 & $\$ 501,651$ & & 143 & 20 & 7,143 & 4 & 0 & - & 49,348 \\
\hline 50 & 999.999 & 100 & & 50.130 & $\$ 523,827$ & & & 25 & & & 0 & 9 & 254,696 \\
\hline 30 & 999,999 & 75 . & $\mathrm{C}$ & 50.130 & $\$ 525,096$ & & 697 & 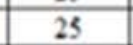 & 429 & 85 . & & $=$ & 234,666 \\
\hline 50 & 999,999 & 100.0 & & 50.133 & $\$ 526,010$ & & & 25 & & & 0 & 0 & 242,830 \\
\hline 50 & 999,999 & 25 & & 50.133 & $\$ 534,365$ & & 85 & - & 29 & 10 & 0 & $\gamma$ & 211,992 \\
\hline 70 & 999.999 & & & 50.140 & $\$ 576,303$ & & & 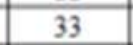 & 75,000 & & 0 & 12 & \\
\hline 70 & 999,999 & 0 & & 50.140 & $\$ 576,660$ & & $\$ 277,269$ & 94 & 75,000 & & 0 & 12 & 211,972 \\
\hline 70 & 999,999 & 100.0 & c & 50.140 & $\$ 577,574$ & 52 & $\$ 278,000$ & 34 & $\$ 275,000$ & & 0 & 12 & 213,443 \\
\hline 70 & 999,999 & & & sin & $\$ 582,113$ & & & & $\$ 275,000$ & & c & 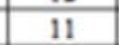 & \\
\hline 80 & 999,999 & 75.6 & c & 50.143 & $\$ 503,994$ & 522,235 & $\$ 316,553$ & 38 & $\$ 314,286$ & 136,288 & 0 & 14 & 204,262 \\
\hline 80 & 999,999 & 100.0 & & S0.141 & 5504,908 & & & 2. & $\$ 314,286$ & & 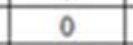 & 14 & 204,321 \\
\hline 80 & 999.999 & & & 50.145 & $\$ 506,828$ & & $\$ 315,796$ & 37 & $\$ 314,286$ & 88 & 0 & 14 & 381 \\
\hline 70 & 999,999 & & & 50.152 & $\$ 508,532$ & & .736 & 25 & $\$ 275,000$ & & 0 & 9 & 383 \\
\hline 80 & 999,999 & & & 50.152 & $\$ 516,309$ & & $\$ 315,436$ & 34 & $\$ 314,286$ & & 0 & 12 & 206,568 \\
\hline 80 & 999,999 & 100.0 & CC & 50.143 & 5504,908 & $\$ 22,249$ & $\$ 317,266$ & 38 & $\$ 314,286$ & 119,252 & 0 & 14 & 204,262 \\
\hline 80 & 999,999 & & & & & & & 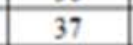 & & & & 14 & \\
\hline 70 & 999.999 & 25.2 & $\mathrm{CC}$ & 50.152 & $\$ 308,532$ & $\$ 25,742$ & $\$ 276,736$ & 25 & $\$ 275,000$ & 119.252 & 0 & 9 & 232.283 \\
\hline 80 & 999,999 & & & 50.1 & $\$ \$ 16,309$ & & & 3 & & & & 12 & 206,509 \\
\hline 80 & 999,999 & 25.2 & $\mathrm{CC}$ & 50.162 & 5548,068 & $\$ 25,761$ & $\$ 3315,042$ & 28 & $\$ 314,286$ & 136,288 & 0 & 9 & 208,966 \\
\hline
\end{tabular}

Figure 9. KIST sensitivity and optimization analysis results.

\begin{tabular}{|l|l|l|l|l|l|l|} 
Month & $\begin{array}{l}\text { Energy } \\
\text { Purchased } \\
(\mathrm{kWh})\end{array}$ & $\begin{array}{l}\text { Energy } \\
\text { Sold }(\mathrm{kWh})\end{array}$ & $\begin{array}{l}\text { Net Energy } \\
\text { Purchased } \\
(\mathrm{kWh})\end{array}$ & $\begin{array}{l}\text { Peak } \\
\text { Demand } \\
(\mathrm{kW})\end{array}$ & $\begin{array}{l}\text { Energy } \\
\text { Charge }(\$)\end{array}$ & $\begin{array}{l}\text { Demand } \\
\text { Charge }(\$)\end{array}$ \\
\hline January & 21,964 & 2 & 21,961 & 51 & $\$ 2,196.20$ & $\$ 0$ \\
February & 19,201 & 0 & 19,201 & 50 & $\$ 1,920.10$ & $\$ 0$ \\
March & 22,722 & 0 & 22,722 & 52 & $\$ 2,272.20$ & $\$ 0$ \\
April & 22,222 & 0 & 22,222 & 51 & $\$ 2,222.20$ & $\$ 0$ \\
May & 22,519 & 0 & 22,519 & 47 & $\$ 2,251.90$ & $\$ 0$ \\
June & 22,595 & 0 & 22,595 & 54 & $\$ 2,259.50$ & $\$ 0$ \\
July & 22,846 & 0 & 22,846 & 51 & $\$ 2,284.60$ & $\$ 0$ \\
August & 23,571 & 0 & 23,571 & 49 & $\$ 2,357.10$ & $\$ 0$ \\
September & 21,633 & 0 & 21,633 & 50 & $\$ 2,163.30$ & $\$ 0$ \\
October & 22,120 & 0 & 22,120 & 46 & $\$ 2,212.00$ & $\$ 0$ \\
November & 21,035 & 0 & 21,035 & 48 & $\$ 2,103.50$ & $\$ 0$ \\
December & 22,196 & 0 & 22,196 & 49 & $\$ 2,219.60$ & $\$ 0$ \\
Annual & 264,624 & 2 & 264,622 & 54 & $\$ 26,462.00$ & $\$ 0$
\end{tabular}




\begin{tabular}{|c|c|c|c|c|c|c|c|}
\hline Month & $\begin{array}{l}\text { Energy } \\
\text { Purchased } \\
\text { (kWh) }\end{array}$ & $\begin{array}{l}\text { Energy } \\
\text { Sold (kWh) }\end{array}$ & $\begin{array}{l}\text { Net Energy } \\
\text { Purchased } \\
(\mathrm{kWh})\end{array}$ & $\begin{array}{l}\text { Peak } \\
\text { Demand } \\
(\mathrm{kW})\end{array}$ & $\begin{array}{l}\text { Energy } \\
\text { Charge (\$) }\end{array}$ & $\begin{array}{l}\text { Demand } \\
\text { Charge (\$) }\end{array}$ & - \\
\hline February & 122 & 24 & 97 & 1 & $\$ 12730$ & 50 & \multirow{11}{*}{$\equiv$} \\
\hline March & 141 & 24 & 117 & 1 & $\$ 148.03$ & so & \\
\hline April & 136 & 20 & 116 & 2 & $\$ 142.89$ & \$o & \\
\hline May & 137 & 18 & 120 & 1 & $\$ 144.39$ & $\$ 0$ & \\
\hline June & 140 & 15 & 125 & 1 & $\$ 146.97$ & \$o & \\
\hline July & 142 & 16 & 126 & 1 & $\$ 149.15$ & $\$ 0$ & \\
\hline August & 147 & 17 & 130 & 1 & $\$ 154.66$ & \$o & \\
\hline September & 135 & 21 & 114 & 1 & $\$ 141.88$ & $\$ 0$ & \\
\hline October & 140 & 21 & 118 & 1 & $\$ 146.74$ & \$o & \\
\hline November & 132 & 19 & 113 & 1 & $\$ 138.56$ & $\$ 0$ & \\
\hline December & 140 & 21 & 120 & 2 & $\$ 147.27$ & $\$ 0$ & \\
\hline Annual & 1,651 & 239 & 1,412 & 2 & $\$ 1,734.20$ & $\$ 0$ & - \\
\hline
\end{tabular}

(b)

Figure 10. Energy operation results (a) KIST and (b) NM-AIST.

\subsection{System Converter}

The results of the systems converters are as shown in Figures 11 and 12 for KIST and NM-AIST respectively

\begin{tabular}{|c|c|c|c|c|c|c|c|}
\hline Quantity & Inverter & Rectifier & Units & Quantity & Inverter & Rectifier & Units \\
\hline Capacity & 25.20 & 22.68 & $\mathrm{~kW}$ & Hours of Operation & $4,338.00$ & 0.00 & $\mathrm{hrs} / \mathrm{yr}$ \\
\hline Mean Output & 5.25 & 0.00 & $\mathrm{~kW}$ & Energy Out & $45,993.00$ & 0.00 & $\mathrm{kWh} / \mathrm{yr}$ \\
\hline Minimum Output & 0.00 & 0.00 & $\mathrm{~kW}$ & Energy in & $51,103.00$ & 0.00 & $\mathrm{kWh} / \mathrm{yr}$ \\
\hline Maximum Output & 25.21 & 0.00 & $\mathrm{~kW}$ & Losses & $5,110.20$ & 0.00 & $\mathrm{kWh} / \mathrm{yr}$ \\
\hline Capacity Factor & 20.83 & 0.00 & $\%$ & & & & \\
\hline
\end{tabular}

Figure 11. KIST - System inverter/converter results.

\begin{tabular}{|l|c|c|c|l|l|l|l|l|}
\hline Quantity & Inverter & Rectifier & Units & Quantity & Inverter & Rectifier & Units \\
\hline Capacity & 5.00 & 4.80 & $\mathrm{~kW}$ & Hours of Operation & 4.326 .00 & 0.00 & $\mathrm{hrs} / \mathrm{yr}$ \\
Mean Output & 0.05 & 0.00 & $\mathrm{~kW}$ & Energy Out & 474.04 & 0.00 & $\mathrm{kWh} / \mathrm{hr}$ \\
Minimum Output & 0.00 & 0.00 & $\mathrm{~kW}$ & Energy In & 493.80 & 0.00 & $\mathrm{kWh} / \mathrm{yr}$ \\
Maximum Output & 0.28 & 0.00 & $\mathrm{~kW}$ & Losses & 19.75 & 0.00 & $\mathrm{kWh} / \mathrm{yr}$ \\
\hline Capacity Factor & 1.08 & 0.00 & $\%$ & & & & &
\end{tabular}

Figure 12. NM-AIST-system inverter/converter results.

\subsection{NM-AIST Storage Battery}

The results of the NM-AIST storage battery shows that autonomy 5.57 hours, other results are as shown in Figures 13 .

\begin{tabular}{|c|c|c|c|c|c|c|c|c|}
\hline Quantity & Value & Units & Quantity & Value & Units & Quantity & Value & Units \\
\hline String Size & \multicolumn{2}{|l|}{200} & \multirow{3}{*}{$\begin{array}{l}\text { Nominal Capacity } \\
\text { Usable Nominal Capacity } \\
\text { Autonomy }\end{array}$} & 200 & $\mathrm{kWh}$ & Energy in & 134 & kWhyr \\
\hline Strings in Parallel & \multicolumn{2}{|l|}{100} & & 120 & $\mathrm{kWh}$ & Energy Out & 107 & $\mathrm{kWh} / \mathrm{yr}$ \\
\hline Batteries & \multicolumn{2}{|l|}{200} & & 557 & he & Storage Depletion & 0.00 & kWh/yr \\
\hline Bus Voltage & 2400 & $\mathrm{v}$ & \multirow{3}{*}{$\begin{array}{l}\text { Lifetime Throughput } \\
\text { Battery Wear Cost } \\
\text { Average Energy Cost }\end{array}$} & 1,60000 & $\mathrm{kWh}$ & Losses & 0.27 & kWhst \\
\hline & & & & 0.10 & $5 / \mathrm{kWh}$ & Annual Throughput & 120 & kWhbr \\
\hline & & & & 105 & s/kwh & Expected Life & 10.00 & $y^{r}$ \\
\hline
\end{tabular}

Figure 13. NM-AIST storage battery results.

\subsection{Emission}

The emissions results suggest that the total amount of each pollutants produced per annum by the existing power system are relatively small to cause emissions with KIST emitting more greenhouse gases than NM-AIST. The major greenhouse gas pollutants include carbon dioxide, carbon monoxide, unburned hydrocarbons and particulate matter, sulfur dioxide, and nitrogen oxides (Figure 14). Therefore, 
sales of power to the grid result in reduced grid emissions.

\begin{tabular}{|l|l|l|}
\hline Quantity & Value & Units \\
\hline Carbon Dioxide & $167,241.00$ & $\mathrm{~kg} / \mathrm{yr}$ \\
\cline { 1 - 2 } Carbon Monoxide & 0.00 & $\mathrm{~kg} / \mathrm{yr}$ \\
Unburned Hydrocarbons & 0.00 & $\mathrm{~kg} / \mathrm{yr}$ \\
Particulate Matter & 0.00 & $\mathrm{~kg} / \mathrm{yr}$ \\
Sulfur Dioxide & 725.06 & $\mathrm{~kg} / \mathrm{yr}$ \\
Nitrogen Oxides & 354.59 & $\mathrm{~kg} / \mathrm{yr}$ \\
\hline
\end{tabular}

(a)

\begin{tabular}{|l|l|l|}
\hline Quantity & Value & Units \\
\hline Carbon Dioxide & 892.29 & $\mathrm{~kg} / \mathrm{yr}$ \\
\cline { 1 - 3 } Carbon Monoxide & 0.00 & $\mathrm{~kg} / \mathrm{yr}$ \\
Unburned Hydrocarbons & 0.00 & $\mathrm{~kg} / \mathrm{yr}$ \\
Particulate Matter & 0.00 & $\mathrm{~kg} / \mathrm{yr}$ \\
Sulfur Dioxide & 3.87 & $\mathrm{~kg} / \mathrm{yr}$ \\
Nitrogen Oxides & 1.89 & $\mathrm{~kg} / \mathrm{yr}$ \\
\hline
\end{tabular}

(b)

Figure 14. Energy emission (a) KIST and (b): NM-AIST.

\section{Conclusion}

This study shows that solar photovoltaics (SPV) systems should be considered as a renewable alternative energy source with high output performance in any simulated supply plan. The simulation results from the HOMER software indicate that $\mathrm{PV}$ is efficient.

The economic analysis of the PV systems showed a low net present cost (NPC) relative to the break-even grid extension distance from the simulated system locations in both NM-ASIT and KIST. However, when the systems were connected to the external grid, the most economically feasible options were feasible because there was no capital costs involved while the operation and maintenance costs were much less compared to the grid system only. In brief, the integration of the solar PV systems presents one of the most environmentally friendly energy options to mitigate greenhouse gas emissions, which simultaneously save against the high initial capital and replacement costs involved with hydroelectric on the grid systems.

\section{References}

[1] Gwang'ombe, F. and N. Mwihava, Renewable in Tanzania: Status and Prospects of Biomass Based Cogeneration and Geothermal Technologies. HBF-HA, Sida/SAREC and AFREPREN/FWD, 2005.

[2] Kassenga, G., The status and constraints of solar photovoltaic energy development in Tanzania. Energy Sources, Part B, 2008. 3 (4): p. 420-432.

[3] Hoffmann, C., E. Romero, and E. Alonso. Combining different controlled-suction techniques to study expansive clays. in Proceedings of the international symposium on advanced experimental unsaturated soils mechanics EXPERUS, Trento, Balkema. 2005.

[4] Hoffmann, W., PV solar electricity industry: Market growth and perspective. Solar energy materials and solar cells, 2006. 90 (18): p. 3285-3311.

[5] Lilienthal, P., HOMER® micropower optimization model, 2005, National Renewable Energy Laboratory (NREL), Golden, CO.

[6] Liu, G., et al., Techno-economic simulation and optimization of residential grid-connected PV system for the Queensland climate. Renewable Energy, 2012. 45: p. 146-155.

[7] Bernal-Agustín, J. L. and R. Dufo-Lopez, Simulation and optimization of stand-alone hybrid renewable energy systems. Renewable and Sustainable Energy Reviews, 2009. 13 (8): p. 2111-2118.

[8] Anwari, M., et al. Photovoltaic power system simulation for small industry area. in Electrical, Control and Computer Engineering (INECCE), 2011 International Conference on. 2011. IEEE.

[9] Ani, V. A. and B. Abubakar, Feasibility Analysis and Simulation of Integrated Renewable Energy System for Power Generation: A Hypothetical Study of Rural Health Clinic. Journal of Energy, 2015. 2015.

[10] González, P., et al. Impact of Grid Connected Photovoltaic System in the Power Quality of a Distribution Network. in DoCEIS. 2011. Springer.

[11] Khatib, T., A. Mohamed, and K. Sopian, A software tool for optimal sizing of PV systems in Malaysia. Modelling and Simulation in Engineering, 2012. 2012: p. 10.

[12] Klein, S., Calculation of monthly average insolation on tilted surfaces. Solar energy, 1977. 19 (4): p. 325-329.

[13] Mishra, S., C. Panigrahi, and D. Kothari, Design and simulation of a solar-wind-biogas hybrid system architecture using HOMER in India. International Journal of Ambient Energy, 2016. 37 (2): p. 184-191. 